\title{
Die Loop van die Dinge
}

Die vorige keer het ek vir ons binne- die begin van die huidige Parlementsitlandse politiek uitgesien na 'n ting saamwerking voorgestel het. SodaNasionale leier wat groot genoeg sal nige saamwerking sal kom, veral as die wees om die nodige reoriëntasie te Engelssprekendes se vrees vir die bewerkstellig, nl. deur inskakeling van Republiek getemper kan word deur dic die Engelssprekende Afrikanerdom en vooruitsig van sekere konstitusionele uitroeping van vryheid as eindbestem- waarborge.

ming vir die nie-blankes; wat die eerste Wat die buitewêreld betref, beweeg betref, met behoud van die nasionale ons geleidelik in die rigting van ' $n$ verontwikkelingslyn, wat die tweede standhouding tussen Amerika en betref, met handhawing van die blanke Rusland, waarna ek al meermale as ' $n$ nasionaliteit.

toekomsmoontlikheid verwys het. Ont-

Dit is opmerklik dat beide mnr. hou daarby dat Amerika en Rusland Strijdom en sir De Villiers Graaff aan beide erfgename is van die Romeinse 
ryk en beide eksponente van die Westerse tegniek.

Dit op sigself sal natuurlik die politieke wêreldkrisis nie oplos nie, maar sal Armageddon kan uitstel en verskuif, moontlik weg van Europa.

I)ie wêreldkrisis self sal egter nog opgelos moet word, naamlik deur 'n beslissing van die alles-oorheersende vraag of wêreld-vereniging sal kom deur internasionale saamwerking of deur kosmopolitiese diktatuur.

Eerste voorwaarde tot die eindbeslissing in die eerste rigting, is die vrymaking van alle leefbare nasies veral in die gekleurde wêreld. En dit is eienaardig dat Ooste en Weste albei in hierdie rigting werk, hoewel met verskillende motiewe en metode en tempo. sowel tussen Ooste en Weste as binne beide.

Wat hierdie vrymaking betref, is die brandpunte, behalwe in Oos-Europa teenoor Rusland en in Suid-Amerika teenoor die Verenigde State, en in Pakistan en Ceylon teenoor Indië, veral gerig teen die nawerking van Europese Imperialisme, wat op sy tyd nuttig was. maar nou haas sy tyd oorleef het.

En hierdie brandpunte is veral geleë in gebiede waar veelrassigheid soos in Suid-Afrika nog nie definitief vervang is deur politieke rassehomogeneïteit nie Want nasionale vryheid is nie bestaanbaar met 'n veelrassigheid wat enige bepaalde leefbare nasionale identiteit sou ondermyn nie.

Dit begin die wêreld nou eers insien, hoofsaaklik as gevolg van die ontwikkeling in Suidelike Afrika, soos enigsins vroeër al ingesien is dat vryheid ook klasseoorheersing uitskakel, 'n soort oorheersing wat egter nog nawerk in baie dele van die wêreld. Hierop wil ons egter nou nie ingaan nie. Ons konsentreer nou op die botsinge tussen nasionale vryheid en veelrassigheid.

Die vernaamste huidige brandpunte hiervan is geleë in Algerië, Nigerië, die Midde-Afrikaanse Federasie, Kenia, Oeganda, Suid-Arabië, die Levant en Ciprus. In verskeie van hierdie gevalle is die oplossing beloof in 1960 .

Die vrymakers is self in bonte verskeidenheid: aan die een kant op ' $n$ afstand: Amerika, Rusland, Egipte en Ghana; en dan meer direk: Engeland en Frankryk, behalwe die betrokke bevolkinge self.

Die meeste van die vrymakers kleef nog vas aan veelrassigheid, maar hierdie stelsel verloor sienderoë veld sowel in Ciprus as in Algerië en ook elders in die genoemde gebiede, soos dit reeds tien jaar tevore prysgegee is ten opsigte van Israel.

Daarteenoor word vrymaking op 'n grondslag van (egte of skynbare) rassehomogeneiteit deur die betrokke bevolkinge met steeds groeiende aandrang geëis in die Griekse wêreld, in Noord-Afrika, in die Nabye Ooste, asook in Wes-, Oos- en Midde-Afrika.

Laasgenoemde kan sonder beswaar toegepas word as die betrokke minderheids-nasionaliteite se integriteit daarby verseker kan bly, wat alleen moontlik is deur internasionaal gewaarborgde gebiedskeiding, soos voorlopig geïllustreer deur Israel en nagestreef in Suid-Afrika en sekerlik moontlik in Midde-Afrika.

L. J. DU PLESSIS. 